\title{
Circular Tourism Perspectives for Oman
}

\section{Sedat YUKSEL}

Associate Professor, MoHE, College of Applied Sciences, Sohar, Sultanate of Oman. sedatyuksel@gmail.com

\begin{abstract}
In this study, it's aimed to introduce circular tourism and to get answer whether if circular tourism will be the leading tourism perspective for the future. As an innovative approach, it is so difficult to generalize the circular solutions for tourism economies in paradoxical context. On one hand, stimulating tourists to spend more, while minimizing wastes as low as possible on the other hand. Recent indicators of circularity performance based on energy, resources, commodities; localization, global relationships and regenerative product design, new business models, reverse logistics and enabling communication technologies. By reviewing best practices in global context, the study focuses on Omani tourism circularity performance.
\end{abstract}

Keywords: Circular tourism, circular economy, sharing destination, Oman

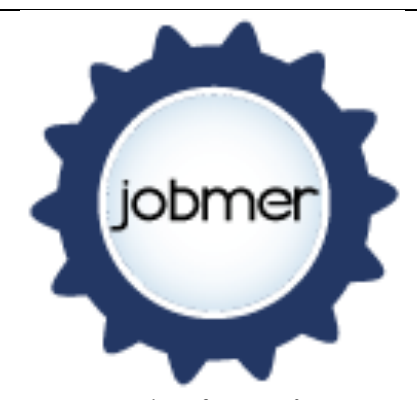

Journal of Business

Management and Economic Research

Vol.1, Issue.1, 2017

pp.1, 13

Doi: 10.29226/jobmer.2017.0

\section{Suggested Citation:}

Yuksel, S., (2017) Circular Tourism Perspectives for Oman, Journal of Business Management and Economic Research, Vol.1, Issue.1, pp.1-13 


\section{INTRODUCTION}

\section{Circularity and Circular Economy}

Circularity has started to influence economical and managerial areas in the second half of the $20^{\text {th }}$ Century. Similar concepts and reflections are sustainability, green economy, collaborative economy and sharing economy before circular economy in literature of economics.

Exponential, limitless economic growth continues, so environmental depletion, degradation, and pollution has now exceeded the planet's carrying capacity. There needs to be a focus on what called "Green GDP" - taking account of environmental degradation and resource depletion. This is particularly important in developing countries like Oman. There are ways that those can be adjusted to avoid depletion of natural resources and degradation of the environment (Stiglitz, 2009). This is despite new environmental accounting methodologies and the application of ethics in modern academic economics (Stern, 2006; Stiglitz, 2002). According to the UNDP 'Global Green New Deal'2 report, environmental policy actions and investments on 'green sectors' address not only the environmental crisis but also most importantly will provide high economic return (UNEP, 2009).

The collaborative economy is a term used to describe a range of more radical business models that represent a shift from product ownership towards rental, leasing or shared access to goods or services (Mearns, 2015). The sharing economy seeks to tap into and unlock idle assets in order to create new wealth and use resources more sustainably (Rinne, 2013).

The vision of a circular economy in which nothing is wasted and everything is a resource is as exciting as it is challenging' (Mearns, 2015). It is an approach that shifts the focus from the ever more efficient use of resources to re-using those resources across the economy (Figure-1). Such an approach not only boosts productivity, by reducing demand for and the cost of raw materials, but also stimulates innovation in terms of product re-design, re-use and remanufacture (Mearns, 2015).

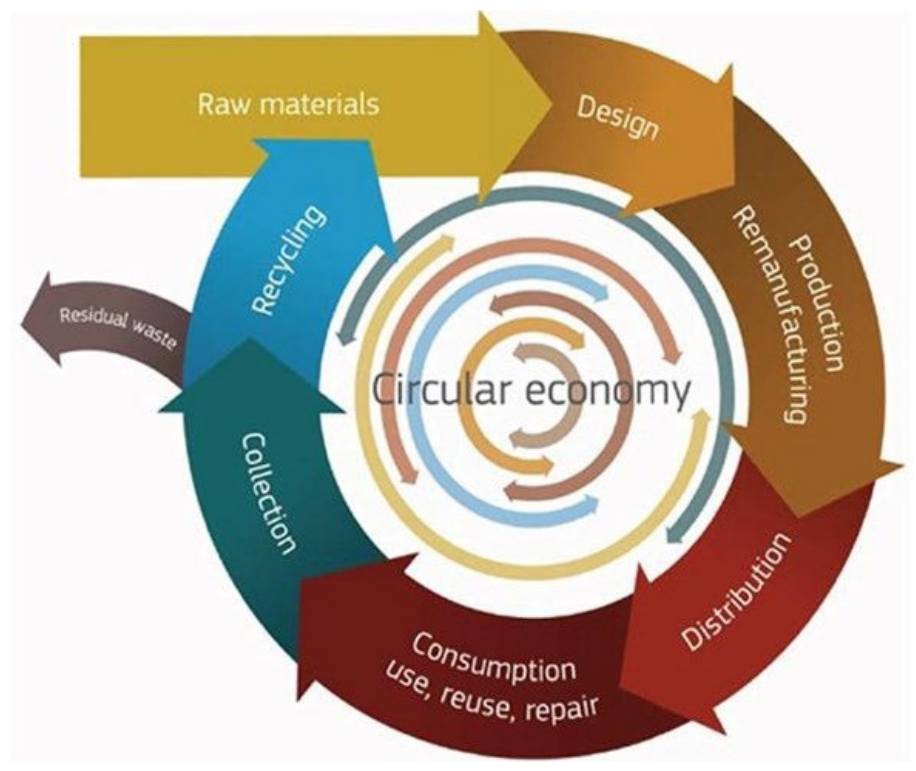

Figure 1 Circular Economy

European Commission (2014) Towards a circular economy:A zero waste programme for Europe, http://ec.europa.eu/environment/circular-economy/pdf/circular-economy-communication.pdf retrieved on 12.02 .17 
It is better to start to emphasize what the contributions of circularity would be to the economy and to businesses. These include:

1. By eliminating wasted materials and maximizing the value of products/services and materials, circularity increases productivity and competitiveness;

2. By working across supply chains to re-design products for a lifetime of disassembly and re-use, circularity stimulates product and service innovation;

3. By developing processes to enable product maintenance and refurbishment rather than disposal, and collaborative use rather than product ownership, circularity builds stronger customer relationships;

4. Circularity means greater resilience in relation to natural and historical assets;

5. By value-creation, customer co-creation, material re-use and recovery, circularity creates jobs, (Mearns, 2015).

When considered at micro level, measuring, understanding and subsequently minimizing resource consumption and waste is critical to the success of a sustainable business model (Lacy and Rosenberg, 2013). Circular thinking presents a vision for how businesses and nations could operate in the 21st century, a vision increasingly supported by leading economies, global businesses and institutions (Drewell and Rutqvist, 2013). It is part of a broader series of trends related to collaborative consumption, production, supply chain management and more that stand to evolve and revolutionize the way business is conducted around the world (Rinne, 2013). The recent study found one-third of global CEOs actively seeking to employ circular economy models (Accenture and UN, 2013).

The recent study (McKinsey, 2015) takes this a stage further and provides a helpful framework to analyze the kinds of business model and technological innovations that comprise the circular economy. The researchers used assumptions about technological and behavioral changes in the period to 2050 to understand where we might expect impacts to be greatest. The 'RESOLVE' framework in Figure-2 describes six broad areas of business opportunity, enabled by new technologies, behaviors and business models (McKinsey, 2015).

\begin{tabular}{|l|cl|}
\hline \multirow{3}{*}{ REGENERATE } & $\checkmark$ & Shift to renewable energy and materials \\
& $\checkmark$ & Reclaim, retain and restore health of ecosystems \\
& $\checkmark$ & Return recovered biological resources to the biosphere \\
\hline \multirow{3}{*}{ SHARE } & $\checkmark$ & Share assets (eg cars, rooms, appliances) \\
& $\checkmark$ & Reuse/second hand \\
& $\checkmark$ & Prolong life through maintenance, design for durability, \\
& & upgradability etc. \\
\hline & $\checkmark$ & Increase the performance / efficiency of products \\
OPTIMISE & $\checkmark$ & Remove waste in production and supply chains \\
& $\checkmark$ & Leverage big data, automation and remote sensing \\
\hline LOOP & $\checkmark$ & Remanufacture products or components \\
& $\checkmark$ & Recycle materials \\
& $\checkmark$ & Digest anaerobically \\
& $\checkmark$ & Extract biochemicals from organic waste \\
\hline VIRTUALISE & $\checkmark$ & Dematerialise directly (eg books, music, films, travel) \\
& $\checkmark$ & Dematerialise indirectly (eg online shopping) \\
\hline EXCHANGE & $\checkmark$ & Replace old with advanced, renewable materials \\
& $\checkmark$ & Apply new technologies (eg 3D printing) \\
& $\checkmark$ & Choose new products/services (eg multimodal transport) \\
\hline
\end{tabular}

Figure 2 RESOLVE Framework 
McKinsey CBE \& Ellen MacArthur Foundation. (2015). Growth within: A circular economy vision for a competitive Europe

https://www.ellenmacarthurfoundation.org/assets/downloads/publications/EllenMacArthurFoundation Growth-Within July15.pdf, retrieved on 12.02.17

McKinsey (2015) applied this framework to three areas of household expenditure, mobility, food and housing, which together account for $60 \%$ of average EU household spend and $80 \%$ of resource consumption. Informed by expert views on technologies to be available by 2020 , they identified significant savings over the period to $2050: 60-80 \%$ for mobility, $25-40 \%$ for food and 25-35\% for housing (Ellen MacArthur Foundation, 2012).

\section{Circular Tourism}

Inevitably, the changes in paradigms of economic development influence on all sectors and subsectors. Although circular business literature has not been developed yet, there are leading examples in e-service sector including Uber Inc., Airbnb Inc. and Lyft Inc. among a growing field.

Based on the "5R"concepts-"rethink, reduce, reuse, recycle, repair" of recycle economy, circular tourism economy has been appeared as a necessary choice to be adopted new paradigms. As inspired from the service sector, tourism industry will find its own circular ways. Figure -3 illustrates briefly changing concepts in tourism sectors past 50 years. Initially, circular business model innovation was driven by small and medium-sized hotels and F\&B businesses. However, bigger international chains are making serious moves.
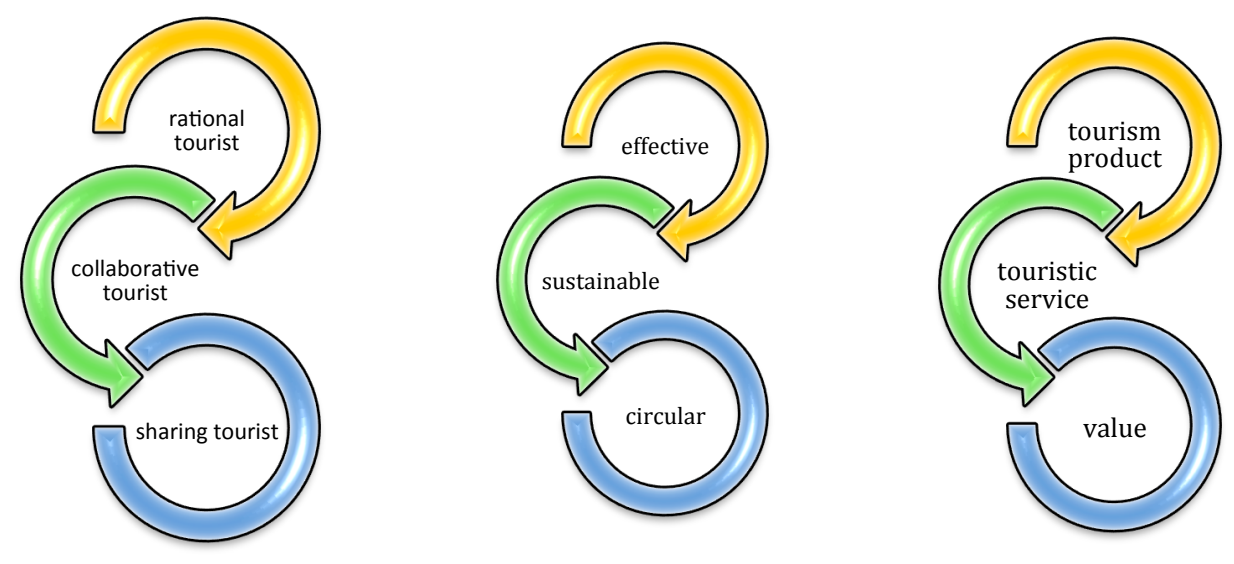

Demand

Economy

Figure 3 Changing Concepts toward Circular Tourism

Supply

As an insight of circular thinking, five fundamental queries can be considered for tourism sector:

- How can the products/services be designed with asset recovery in mind?

- How can the product lines be developed to meet demand without wasting assets?

- How can the material be sourced in regenerative loops rather than linear flows?

- How can a revenue model be developed that protects value up and down the chain?

- How to make the customers being cooperative? (Drewell and Rutqvist, 2013).

In order to adopt circular approaches into tourism businesses, these can be primarily considered by decision makers: 


\section{Circular Supply-Chain Management for Tourism Business}

When a hotel needs resources that are scarce or environmentally destructive, it can either pay more or find alternative resources. The Circular Supply-Chain introduces fully renewable, recyclable or biodegradable materials that can be used in consecutive lifecycles to reduce costs and increase predictability and control.

\section{Recovery E Recycling}

The Recovery \& Recycling model creates production and consumption systems in which everything that used to be considered waste is revived for other uses. For tourism businesses either recover end-of-life products to recapture and reuse valuable material, energy and components or they reclaim waste and by-products from a delivery process. Starbucks, for example, is actually aiming to turn thousands of tons of its waste coffee grounds and food into everyday products by using bacteria to generate succinic acid which can then be used in a range of products from detergents to bio-plastics and medicines.

\section{Tourism Product/ Destination Life-Extension}

Tourists discard destinations and or tourism products/services they no longer value-because the destinations are overcrowded, out of fashion or damaged. But many of those still hold considerable value, and this model seeks to recapture it. By maintaining and improving tourism products and touristic services through, redesigning, upgrades, remanufacturing or remarketing, destinations can keep them economically useful for as long as possible. It also means moving tourists from transactions to relationships, tailoring upgrades and alterations to specific needs.

\section{Sharing Platform}

The Sharing Platform model-increasingly assisted by new forms of digital technologyforges new relationships and business opportunities for tourists, companies and microentrepreneurs, who rent, share, swap or lend their idle assets. Tourism businesses may share their facilities to decrease using energy and other inputs at the same destination. For example especially for Small and Medium-Sized Hotels share laundries, swimming pools, restaurants, kitchens, pubs, as well as idle rooms of residents in the destination. Lastly, social media exchange platforms are rapidly transforming industries by collaborative consumption. Airbnb (the online service that matches people seeking vacation rentals with hosts who have space) now has over 200,000 listings in 26,000 cities.

For better understanding of the basis of circular tourism, those can be listed below:

- Create innovation that play a leading role in assisting tourism to adapt to new circular, sustained economic conditions,

- Reinforce tourism resilience and economic importance through stronger investment in human resources, better market knowledge and in technology.

- Encourage adaptation of innovative practices and increase the uptake of technology by all stakeholders.

- Maximize cooperation and synergy between all national, regional and international stakeholders;

- Coo-petition (cooperation in competition) can extend beyond traditional frameworks into economic, employment and development areas as well as among destinations. 


\section{Tourism in Oman}

Although the tourism industry in Oman is comparatively new and a relatively small part of the total economy, it has been growing quite rapidly. As given on Table- 1 , the direct contribution of Travel \& Tourism to GDP in 2014 was OMR765.1mn (2.6\% of GDP). This primarily reflects the economic activity generated by industries such as hotels, travel agents, airlines and other passenger transportation services. But it also includes, for example, the activities of the restaurant and leisure industries directly supported. The total contribution of Travel \& Tourism to GDP including wider effects from investment, the supply chain and induced income impacts, was OMR1,697.5mn in 2014 (5.7\% of GDP)(WTTC, 2015).

In 1995, the "Vision Oman 2020" stipulated the diversification of the national economy away from oil. For the first time, it also proposed serious policies encouraging the development of tourism (Wippel, 2015). The programme's aim is to increase non-oil GDP to $81 \%$ of GDP by 2020 (EHER, 2015). The direct contribution of Travel \& Tourism to GDP is expected to grow by $6.1 \%$ per annum to OMR1,453.5mn (3.3\% of GDP) and the total contribution of Travel \& Tourism to GDP to rise by $6.2 \%$ per annum to OMR3,222.3mn by 2025 (7.3\% of GDP) (WTTC 2015).

Besides direct and total contribution to GDP, direct and total contribution to employment also cannot be ignored. Travel \& Tourism generated 44,500 jobs directly in 2014 ( $2.8 \%$ of total employment). This includes employment by hotels, travel agents, airlines and other passenger transportation services (excluding commuter services). It also includes, for example, the activities of the restaurant and leisure industries directly supported by tourists. The total contribution of Travel \& Tourism to employment (including wider effects from investment, the supply chain and induced income impacts) was 90,500 jobs in 2014 (5.7\% of total employment). By 2025, Travel \& Tourism will account for 72,000 jobs directly, an increase of $3.8 \%$ per annum as well as, direct and indirect 143,000 jobs in total $(7.5 \%$ of total employment), an increase of $3.8 \%$ per annum over the period (WTTC, 2015).

Domestic travel spending generated 39.3\% of direct Travel \& Tourism GDP in 2014 compared with $60.7 \%$ for visitor exports (ie foreign visitor spending or international tourism receipts) per annum to OMR769.0mn in 2025. International tourist arrivals are forecast to total $3,493,000$, generating expenditure of OMR1,565.0mn, an increase of $7.1 \%$ per annum by 2025 (WTTC, 2015).

Omani Ministry of Tourism emphasizes its ' mission in a sustainable frame and states 'tourism will facilitate economic diversification, preservation of cultural integrity and protection of the environment of the Sultanate of Oman, ' in the mission statement. Besides, The Vision is stated stronger expression and higher dedication of sustainability in tourism development as 'Tourism will be developed as an important and sustainable socio-economic sector of the Sultanate of Oman in a manner that reflects the Sultanate's historic, cultural and natural heritage and ethos of traditional hospitality, '(Ministry of Tourism, 2010).

\section{Table 1 Summarized Facts and Figures of Omani Tourism}




\begin{tabular}{|c|c|c|c|c|c|c|}
\hline Oman & $\begin{array}{c}2014 \\
\text { US }^{2} \mathrm{mn}^{1}\end{array}$ & $\begin{array}{c}2014 \\
\% \text { of total }\end{array}$ & $\begin{array}{c}2015 \\
\text { Growth }^{2}\end{array}$ & US $\$ m n^{1}$ & $\begin{array}{c}2025 \\
\% \text { of total }\end{array}$ & Growth $^{3}$ \\
\hline Direct contribution to GDP & $1,989.7$ & 2.6 & 5.2 & $3,779.8$ & 3.3 & 6.1 \\
\hline Total contribution to GDP & $4,414.4$ & 5.7 & 3.8 & $8,379.6$ & 7.3 & 6.2 \\
\hline Direct contribution to employment ${ }^{4}$ & 44.5 & 2.8 & 11.0 & 71.8 & 3.7 & 3.8 \\
\hline Total contribution to employment ${ }^{4}$ & 90.6 & 5.7 & 9.4 & 143.4 & 7.5 & 3.8 \\
\hline Visitor exports & $1,934.2$ & 3.7 & 6.0 & $4,070.0$ & 5.7 & 7.1 \\
\hline Domestic spending & $1,252.5$ & 1.6 & 8.9 & $1,999.8$ & 1.7 & 3.9 \\
\hline Leisure spending & $2,273.0$ & 1.8 & 10.2 & $4,605.8$ & 2.5 & 6.3 \\
\hline Business spending & 913.7 & 0.7 & -0.5 & $1,464.0$ & 0.8 & 4.9 \\
\hline Capital investment & 694.5 & 3.6 & 10.3 & $1,407.0$ & 3.9 & 6.3 \\
\hline
\end{tabular}

${ }^{1} 2014$ constant prices \& exchange rates, ${ }^{2} 2015$ real growth adjusted for inflation $(\%) ;{ }^{3} 2015-2025$ annualised real growth adjusted for inflation (\%); ${ }^{4} 000$ jobs

World Travel \&Tourism Council. (2015). Travel \& Tourism Economic Impact 2015 Oman, London: page 11

Oman can improve her tourism product by monitoring trends in sustainable tourism. There are many special interest tourism types considerable for improving sustainable tourism product. It is a generally accepted opinion that ecofriendly, well-preserved, green-blue combined tourism products are always favored by worldwide tourism markets. Green-blue combined tourism product also extends the length of stay and increases tourism income indirectly. Mechanisms should b-e funded for the development of 'green' tourism products and services such as hiking, cycling, ecotourism, and rural tourism (Yuksel, 2014).

A major focus for tourism development over the forthcoming years is for Oman is to develop a whole range of tourism products that will widen its perceived tourism product portfolio. Examples of new products will include (Deloitte and Touche, 2008):

- Round the country Tours

- Yachting Ports, Marinas, Shelter Harbors

- Eco-tourism

- Health and Spas Tourism

- Adventure Tourism

- Diving

- Cultural tourism

- Event tourism

- Cruise shipping

- MICE (Meeting, Incentive, Conference, Exhibition) tourism

- Farm tourism

\section{CRITICAL APPROACH TO CIRCULARITY OF OMANI TOURISM}

In this chapter, by using global data, Omani tourism circularity performance will be evaluated and compared with leading circular economies and similar contexts in Arabian Gulf. In order to evaluate circular performance of economy, despite there are many direct and indirect indicators and criteria, due to data availability, it will be preliminary comparison about followings:

- GDP

- GDP Per Capita

- Human Development Index

- Ranking of Happiness

- Easy of Doing Business

- Travel \& Tourism competitiveness index 
- Logistics Performance Index

- Knowledge based Economy

- Corruption perception Index

- Global sustainability Competitiveness Index

Table 2 Comparison between Oman and Leading Circular Economies

\begin{tabular}{|c|c|c|c|c|c|c|}
\hline 2015 Global Comparisons & Oman & NL & DK & SE & $\mathrm{CH}$ & FI \\
\hline GDP & 62 & 17 & 33 & 21 & 20 & 40 \\
\hline GDP Per Capita & 40 & 12 & 7 & 8 & 5 & 16 \\
\hline Human Development & 52 & 5 & 4 & 14 & 3 & 24 \\
\hline Ranking of Happiness & 22 & 7 & 3 & 8 & 1 & 6 \\
\hline Easy of Doing Business & 70 & 28 & 3 & 8 & 26 & 10 \\
\hline Travel \& Tourism & 65 & 14 & 27 & 23 & 6 & 22 \\
\hline Logistics Performance & 59 & 2 & 17 & 6 & 14 & 24 \\
\hline Knowledge based & 47 & 4 & 3 & 1 & 10 & 2 \\
\hline Corruption perception & 45 & 87 & 91 & 89 & 86 & 90 \\
\hline Global sustainability & 61 & 28 & 9 & 2 & 5 & 4 \\
\hline \multicolumn{7}{|c|}{$\begin{array}{l}\text { Adopted by Oman Global Standing Data (2016), http://globalstanding.ncsi.gov.om/ retrieved } \\
\text { on 10.01.2017 } \\
\text { Table-2 shows the comparison between leading circular economies (NL for Netherland, DK } \\
\text { for Denmark, SE for Sweden, CH for Switzerland, FI for Finland) and Oman by global } \\
\text { ranking. As seen on the Table-2 Northern European Economies are leading on considerations } \\
\text { directly and/or indirectly linked circularity. Except, Corruption Perception Index, descending } \\
\text { numbers are better positions in global context. } \\
\text { Table } 3 \text { Comparison between Oman and Other GCC Economies }\end{array}$} \\
\hline 2015 Global Comparisons & Oman & KSA & UAE & Qatar & Kuwait & Bahrain \\
\hline GDP & 5 & 1 & 2 & 3 & 4 & 6 \\
\hline GDP Per Capita & 6 & 5 & 2 & 1 & 3 & 4 \\
\hline Human Development & 6 & 2 & 3 & 1 & 5 & 4 \\
\hline Ranking of Happiness & 2 & 4 & 1 & 3 & 5 & 6 \\
\hline Easy of Doing Business & 4 & 5 & 1 & 3 & 6 & 2 \\
\hline
\end{tabular}


Journal of Business Management and Economic Research

$\begin{array}{lllllll}\text { Travel \& Tourism } & 5 & 4 & 1 & 2 & 6 & 3 \\ \text { Logistics Performance } & 6 & 3 & 1 & 2 & 5 & 4 \\ \text { Knowledge based } & 3 & 4 & 1 & 5 & 6 & 2 \\ \text { Corruption perception } & 6 & 3 & 2 & 1 & 5 & 4 \\ \text { Global sustainability } & 2 & 1 & 5 & 3 & 4 & 6\end{array}$

Adopted by Oman Global Standing Data 2016, http://globalstanding.ncsi.gov.om/ retrieved on 10.01 .2017

Table-3 shows the comparison between GCC economies (KSA for Kingdom of Saudi Arabia, UAE for United Arab Emirates) and Oman by regional ranking. Regional ranking data have been modified from global data. As seen on the Table, despite Oman is not leading economy in the Gulf in any circularity symptoms, has relatively better ranks in Happiness and Global Sustainability Competitiveness Index.

Oman ranks 70 out of 189 countries rated by the World Bank's Ease of Doing Business 2016 Survey, and positive aspects include registration of property, the tax system from a business perspective and trading across borders. Economic freedoms are constrained by continuing state involvement in the private sector and the energy sector remains largely state-owned (EHER, 2015).

On the way of circular tourism, in order to evaluate and compare Omani tourism performance with other contexts, Table 4 gives indexes and pillars of competitiveness in travel and tourism. It can be said Oman is not far away to circularity in general.

Table 4 Oman: Travel and Tourism Competitiveness Index and Pillars (2015) Value 1-7 highest

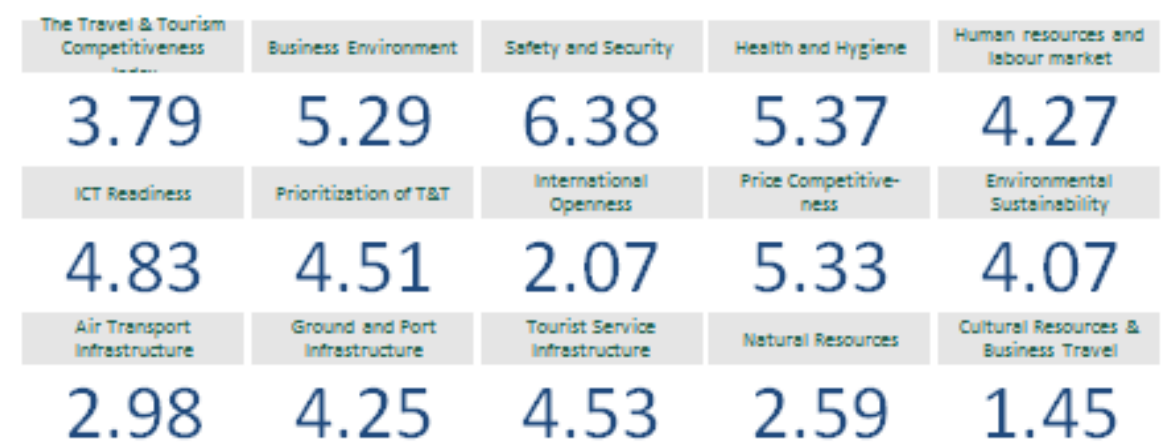

http://globalstanding.ncsi.gov.om/boqwwyb/the-travel-and-tourism-competitiveness index? lang=en. Retrieved on $2 / 7 / 2017$

After comparing and evaluating Omani tourism circularity performance, seems to be more convenient to analyze by SWOT. Figure-4 is designed for SWOT Analysis of Omani circular tourism. 


\begin{tabular}{|l|l|}
\hline \multicolumn{1}{|c|}{ Strengths } & \multicolumn{1}{c|}{ Weaknesses } \\
Young population & Import-dependent production \\
Higher computer literacy & Lack of natural reserves \\
Higher happiness & Agricultural production capabilities \\
Unutilized and unpolluted fields & Seasonality in tourism \\
Social solidarity & Poor productivity in both sector \\
Safety and security & Public-dominant economy \\
Sustainable competitiveness & Innovative business ideas \\
Emerging destination & Poor performance in service sector \\
Hospitable society & Poor logistic infrastructure \\
Unique and eccentric culture & Supply chain management \\
\hline \multicolumn{1}{|c|}{ Opportunities } & \multicolumn{1}{c|}{ Threats } \\
& Water resources \\
The increase of food demands & Energy shortage \\
Renewable energy potentials & Vulnerable hydrocarbon sector \\
Regional investors & Unemployment \\
Organic production & Global and Regional conflicts \\
& Climate change \\
\hline
\end{tabular}

Figure-4 SWOT Analysis of Oman Circular Tourism

\section{Milestones}

In Oman, tourism needs to be integrated into national, regional and international legislation/regulations that encompass and encourage circular economy strategies. As preliminary steps, sustainable development strategies as well as green economy like green employment, green investment, planning, procurement, fuel efficiency and renewable energy programs must be prioritized at macro and destination level of tourism policy and planning in Oman. There are many ways that public and private sectors can learn about and get meaningfully involved in the sharing economy.

The first step is understanding the drivers and principles that enable new tourism business models and ways to create value to evolve. At this step for business and private sector leaders, recommendations below are intended to serve as guidelines for better understanding of:

- The potential effects of collaborative consumption models in tourism sector and business.

- Lessons and insights that incumbents have already learned, such as focusing on underlying drivers affecting why people opt for collaborative consumption models:

- The attractiveness, rationale and diversity of collaborative consumption funding options for investors and entrepreneurs

In order to promote innovation, seeking partnerships and joint ventures that enable leveraging of assets, inventory and expertise will be the second step. Thirdly, investigate nonmonetary value creation, resilience strategy, and non-monetary and other qualitative performance metrics.

On the other hand, like in Oman, centralized and planned tourism policy-makers need to consider recommendations below for circular tourism economy:

- Identifying opportunities to create and promote a "shareable destination"

- working with municipal agencies to develop and implement appropriate legal and regulatory mechanisms for access based and collaborative forms of business, consumption, production and exchange 
- collecting data on consumption and waste patterns within the destination, which gives a foundation for companies to build business models and attract funding (Rinne, 2013).

\section{CONCLUSION}

The adoption of sharing economy principles, systems and drivers has the potential to reshape business models and create valuable opportunities for companies - large and small, start-up and established - who can understand and harness the advantages available (Rinne, 2013). Circular tourism could require a mixture of circular business models and a great deal of product and service innovation Carefully choose the business model that is right for their business, recognizing there is no one "right" answer for all companies to succeed in the circular economy. In implementing new circular business models, they make sure to identify and capitalize on external enablers and business ecosystems (Dresdell \& Rutqvisk, 2013).

With its circular economy proposals, Government is taking a big step towards realizing its overarching purpose of making economic growth truly sustainable. Public authorities and destination groups have a key role to play in the full realization of what the sharing economy could become for circular and shareable destinations (Rinne, 2013). Tourists have a central role too. Given the interdependent strands of the circularity framework, success will depend on strong partnerships between Government, public sector partners and crucially, the private sector.

There is still a need for further, in-depth research on where the greatest opportunities lie and how they can best be realized in order to translate the vision into reality. Also required are more relevant statistics to track progress together with more consistent, economy-wide methodologies to be able to accurately assess the opportunities (Mearns, 2015).

The evidence of the broad benefits of a circular approach is clear, both at a national and destination levels in Oman. Though true circularity is not achievable in the short term, Oman is able to learn from others as their visions become reality. Macro economical forces will lead moreover shape circularity in Oman. Omani tourism should take GCC countries advantage, not only as competitors but also collaborator markets. Logistics and supply chain should be improved in circular way. Nationwide perspective should be circular economy, then tourism. The highest awareness and sustainable policies on water reserves, consumption and quality are vital important. 
Yuksel S., 2017, Vol.1, Issue.1, pp.1-13

\section{REFERENCES}

Accenture \& UN. (2013). The UN Global Compact-Accenture CEO Study on Sustainability 2013: Architects of a Better World, September 2013, https://acnprod.accenture.com/usen/insight-un-global-compact-ceo-study-sustainability-2013.

Deloitte \& Touche. (2008). Oman Hotel Demand and Supply Study, Retrieved on 20 December 2009

from http://consys.omantourism.gov.om/wps/wcm/resources/file/eb10dc015a567c7/Oman_Hotels_ Information_En.pdf

Drewell, Q. \& Rutqvist, J. (2013). Circular Economy - the key is the business model, Article Series, Circular Economy Innovation \& New Business Models Initiative WEF, YGLT, Davos.

EHER (Euler Hermes Economic Research). (2015). Country Report Oman, http://www.eulerhermes.com, retrieved on 2015-12-17

Ellen MacArthur Foundation. (2012).Towards the Circular Economy Vol. 1: an economic and business rationale for an accelerated transition, London 


\section{Journal of Business Management and Economic Research}

European Commission (2014) Towards a circular economy:A zero waste programme for Europe, http://ec.europa.eu/environment/circular-economy/pdf/circular-economy-communication.pdf retrieved on 12.02 .17

Lacy, P. \& Rosenberg, D. (2011). Cradle to Cradle and Evolutionary Business Models, Article Series, Circular Economy Innovation \& New Business Models Initiative, WEF, YGLT, Davos.

McKinsey CBE \& Ellen MacArthur Foundation. (2015). Growth within: A circular economy vision for a competitive Europe https://www.ellenmacarthurfoundation.org/assets/downloads/publications/EllenMacArthurF oundation_Growth-Within_July15.pdf, retrieved on 12.02.17

Mearns, E. (2015). Re-designing a more circular Scottish economy, Economic Commentary, Scottish Enterprise and Daniel Hinze, Government Economic Service University of Strathclyde I Fraser of Allander Institute, 39 (2) November.

Ministry of Tourism. (2010). Sultanate of Oman, National Tourism Development Plan, $\begin{array}{lllll}\text { Retrieved on } & 05 & \text { January } & 2010 & \text { from }\end{array}$ http://consys.omantourism.gov.om/wps/wcm/resources/file/ebff410b97de37c/Tourism_Strati gey_in_Oman.doc

National Center of Statistics and Information (2016). Oman Global Stand http//globalstanding.ncsi.gov.om

Rinne, A. (2013). Circular Economy Innovation \& New Business Models Initiative, Young Global Leaders Sharing Economy Working Group, Position Paper, WEF, YGLT, Davos

Stern, N. (2006). Stern Review on the Economics of Climate Change. Retrieved on December 2009 from http://www.hm-treasury.gov.uk/sternreview_index.htm

Stiglitz, J.E. (2002). Ethics, Economic Advice, and Economic Policy. The Inter-American Initiative on Social Capital, Ethics and Development, Buenos Aires, Argentina. Retrieved on 05 January 2010 from http://www.iadb.org/etica/documentos/dc_sti_ethic-i.pdf

--- (2009). Nobel Laureate Joseph Stiglitz on Sustainability and Growth. Retrieved on 05 January 2010 from

http://open.salon.com/blog/jay_kimball/2009/02/20/nobel_laureate_joseph_stiglitz_on_sustain ability_and_growth

UNEP (United Nations Environment Program). (2009). Global Green New Deal - An Update for the G20 Pittsburgh Summit, http://www.unep.org/pdf/G20_policy_brief_Final.pdf retrieved on 12.02 .17

Wippel, S. (2015). Salalah "Paradise": The Emergence of a New Tourism Destination in Southern Oman, Syddansk Universitet, Denmark.

Yuksel, S. (2014). Roadmap Of Recovery Amid Challenges Facing Oman Tourism, Omani Journal of Applied Sciences, Vol 5. 